\begin{tabular}{|c|l|}
\hline Title & Late Jurassic-Early Cretaceous intra arc sedimentation and volcanism linked to plate motion change in northern Japan \\
\hline Author(s) & TA KA SHIMA, REISHI; NISHI, HIROSHI; Y OSHIDA, TA KEY OSHI \\
\hline Citation & $\begin{array}{l}\text { Geological Magazine, 143(6), 753-770 } \\
\text { https://doi.org/10.1017/5001675680600255X }\end{array}$ \\
\hline Issue Date & 2006-11 \\
\hline Doc URL & http://hdl.handle.net/2115/17119 \\
\hline Rights & Copyright $\odot 2006$ Cambridge University Press \\
\hline Type & article \\
\hline File Information & GM1436.pdf \\
\hline
\end{tabular}

Instructions for use 


\title{
Late Jurassic-Early Cretaceous intra-arc sedimentation and volcanism linked to plate motion change in northern Japan
}

\author{
REISHI TAKASHIMA* $\dagger$, HIROSHI NISHI* \&TAKEYOSHI YOSHIDA \\ *Department of Earth and Planetary Science, Graduate School of Science, Hokkaido University, \\ N10W8, Kita-ku, Sapporo, 060-0810, Japan \\ $\ddagger$ Institute of Mineralogy, Petrology and Economic Geology, Graduate School of Science, Tohoku University, \\ Aoba-ku, Sendai, 980-8567, Japan
}

(Received 5 October 2005; accepted 10 January 2006)

\begin{abstract}
The Sorachi Group, composed of Upper Jurassic ophiolite and Lower Cretaceous island-arc volcano-sedimentary cover, provides a record of Late Jurassic-Early Cretaceous sedimentation and volcanism in an island-arc setting off the eastern margin of the Asian continent. Stratigraphic changes in the nature and volume of the Sorachi Group volcanic and volcaniclastic rocks reveal four tectonic stages. These stages resulted from changes in the subduction direction of the Pacific oceanic plate. Stage I in the Late Jurassic was characterized by extensive submarine eruptions of tholeiitic basalt from the back-arc basin. Slab roll-back caused rifting and sea-floor spreading in the supra-subduction zone along the active Asian continental margin. Stage II corresponded to the Berriasian and featured localized trachyandesitic volcanism that formed volcanic islands with typical island-arc chemical compositions. At the beginning of this stage, movement of the Pacific oceanic plate shifted from northeastward to northwestward. During Stage III, in the Valanginian, submarine basaltic volcanism was followed by subsidence. The Pacific oceanic plate motion turned clockwise, and the plate boundary between the Asian continent and the Pacific oceanic plate changed from convergent to transform. During Stage IV in the Hauterivian-Barremian, in situ volcanism ceased in the Sorachi-Yezo basin, and the volcanic front migrated west of the Sorachi-Yezo basin.
\end{abstract}

Keywords: Cretaceous, Jurassic, island-arc, volcanism, tectonics, Asia.

\section{Introduction}

The Late Jurassic-Early Cretaceous period was characterized by a significant reconfiguration of the continents and oceanic plate movement in the NW Pacific (Kirillova, 2003a,b; Nakanishi, Tamaki \& Kobayashi, 1992; Ren et al. 2002). During this interval, continental Siberia collided with both the combined MongoliaChina and the Omolon-Kolyma continents along its southern and eastern margins, respectively (Oxman, 2003; Van der Voo, Spakman \& Bijwaard, 1999; Zonenshain, Kuzmin \& Natapov, 1990). These collisions resulted in the formation of the amalgamated Asian continent. Subsequently, the conjugation between the Asian continent and the oceanic plate below the Pacific Ocean (the Farallon-Izanagi plate) changed from a convergent to a transform boundary (Engebretson, Cox \& Gordon, 1985). Many studies have confirmed that this change in Pacific oceanic plate movement halted the growth of accretionary complexes and induced the northeastward migration of the NE Japan Block during the Early Cretaceous period (e.g. Takahashi \& Matsukawa, 2000; Tazawa, 2002). Although this change in plate movement is thought to be reflected in subduction-related volcanism, little is known about the temporal-spatial changes in

†Author for correspondence: rtaka@nature.sci.hokudai.ac.jp
Early Cretaceous supra-subduction volcanism along the active continental margin of Asia.

The Horokanai Ophiolite and Sorachi Group, represented by the Upper Jurassic ophiolites and their Lower Cretaceous island-arc volcano-sedimentary covers, are exposed in central Hokkaido, northern Japan (Ishizuka, 1980; Takashima, Yoshida \& Nishi, 2002). As these strata are biostratigraphically well studied based on well-preserved microfossils and exhibit continuous succession without significant unconformity, they are suitable for clarifying the Late Jurassic-Early Cretaceous geodynamic evolution of the island-arc system of Asia. Using the history recorded in these strata, this paper reconstructs the temporal-spatial evolution of the volcanic and sedimentary basins of central Hokkaido during the Late Jurassic-Early Cretaceous period and clarifies the linkage between the volcanotectonic evolution of the island-arc system and the change in Pacific oceanic plate movement.

\section{Regional geological setting}

The Japanese Islands are now separated from the Asian continent, but were an eastern constituent of the continent before the Miocene opening of the Japan Sea. They are mainly composed of upper Palaeozoic to Cenozoic accretionary complexes constructed along 


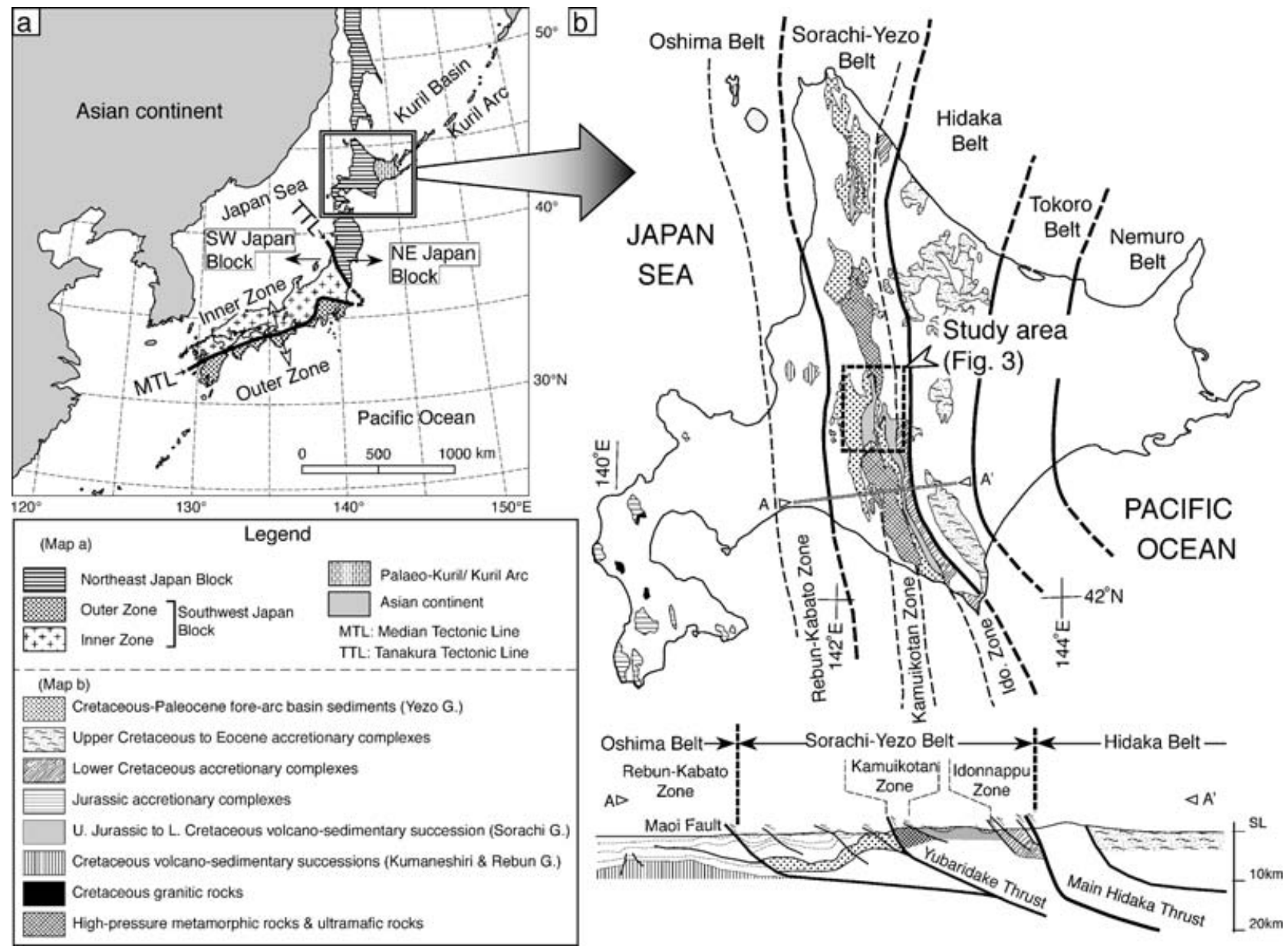

Figure 1. (a) Simplified geological map and (b) structural profile showing the distribution of the Mesozoic formations of Hokkaido. Dashed rectangle in (b) marks the study area. Structural profile is modified from Ito (2002).

the East Asian continental margin, which have been intruded and covered by volcano-plutonic rocks. Structurally, the Japanese Islands are mainly divided into two blocks (the NE Japan and SW Japan blocks) by the Tanakura Tectonic Line (TTL) (Fig. 1a). The SW Japan Block is subdivided into the Inner and Outer zones by the Median Tectonic Line (MTL) (Fig. 1a). Both tectonic lines were originally a series of largescale left-lateral strike-slip fault systems which have been active since Early Cretaceous times. The NE Japan Block and the Outer Zone of the SW Japan Block were originally located southwest of the Inner Zone of the SW Japan Block, and migrated northeastward along the MTL-TTL after the Early Cretaceous (e.g. Osozawa, 1994; Tazawa, 2002).

The island of Hokkaido is tectonically subdivided into the western and eastern sub-blocks which collided during Palaeogene times along the Hidaka Belt of a lower Palaeogene accretionary complex (Fig. 1b). Western Hokkaido is the northernmost constituent of the NE Japan Block, while eastern Hokkaido, represented by the Tokoro and Nemuro belts, is the Palaeo-Kuril island-arc (Fig. 1b). The Mesozoic rocks exposed in western Hokkaido can be divided into two N-S-trending tectonostratigraphic divisions. From west to east, these belts are the Oshima (a late EarlyLate Cretaceous volcanic arc on a Jurassic accretionary complex), Sorachi-Yezo (a Late Jurassic-early Early Cretaceous island-arc and late Early CretaceousPaleocene fore-arc basin and accretionary complex), as shown in Figure 1b (Kiminami et al. 1986). Cretaceous submarine volcano-sedimentary successions (the Rebun and Kumaneshiri groups), distributed along the eastern margin of the Oshima Belt, are distinguished as the Rebun-Kabato Zone (Fig. 1b) from the Cretaceous granitic rocks of the western Oshima Belt. These divisions formed along the $\mathrm{W}$-dipping subduction zone of the Pacific oceanic plate (Farallon, Izanagi and Kula plates) under the eastern margin of the Asian continent (Okada, 1974).

The Sorachi-Yezo Belt and the Rebun-Kabato Zone were deformed by dextral slip and block-like rotation during the Oligo-Miocene due to the opening of Kuril Basin (Jolivet, Shibuya \& Fournier, 1995; Takeuchi, Kodama \& Ozawa, 1999). Furthermore, they were shortened by collision caused by the southwestward migration of the Kuril fore-arc sliver beginning in the Miocene (Kimura, 1985), resulting in the development of N-S-trending thrust and fold systems within the belts (Fig. 1b). The lateral shortening distance in 


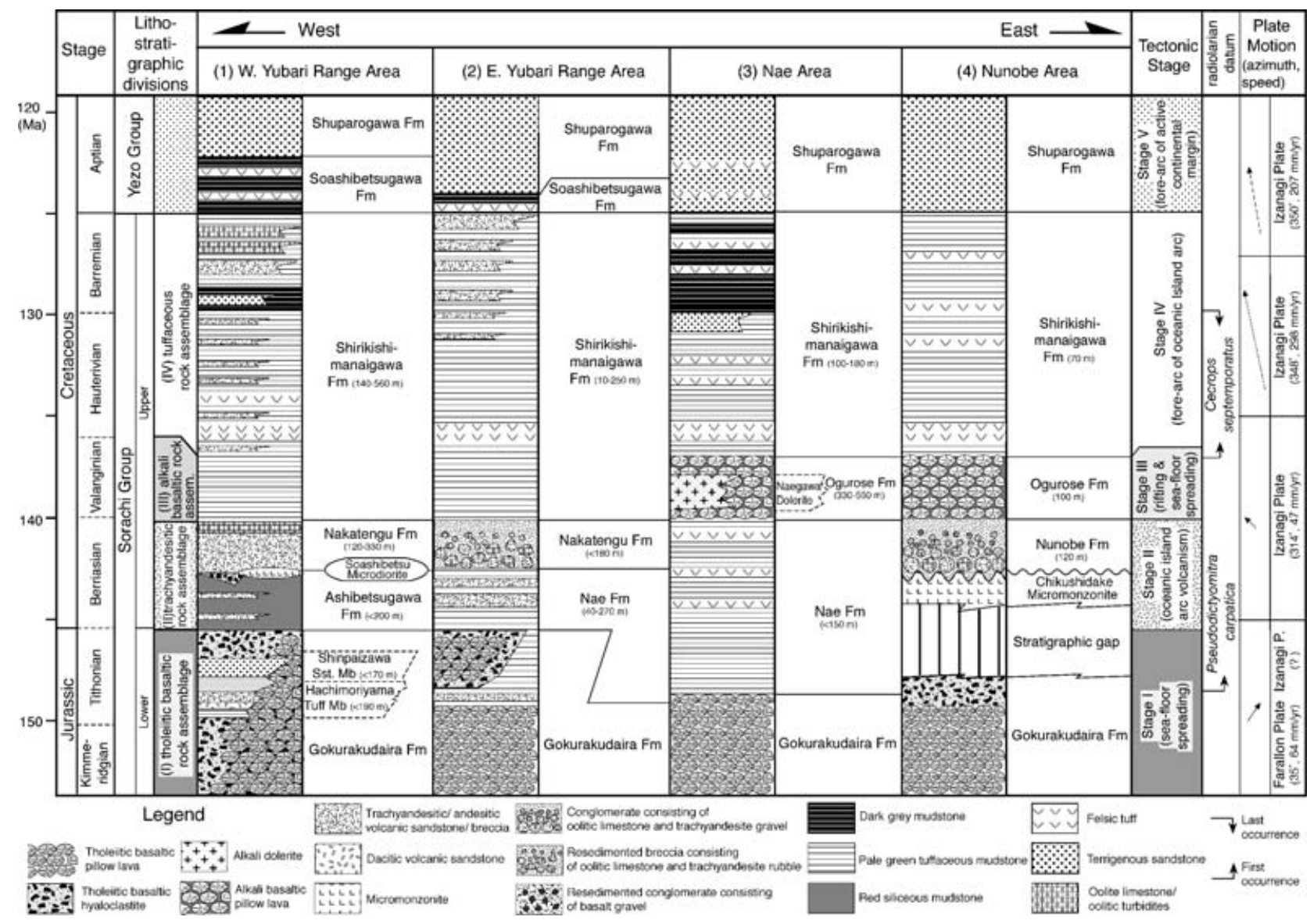

Figure 2. Generalized isochronous stratigraphic nomenclature of the Sorachi Group for the four sections studied in this region. Pacific oceanic plate motion is from Engebretson, Cox \& Gordon (1985). Time scale is from Ogg, Agterberg \& Gradstein (2004).

central Hokkaido is considered to be $60 \mathrm{~km}$ (Ito, 2002).

The Sorachi-Yezo Belt consists of a continuous succession from the Horokanai Ophiolite through the Sorachi Group to the Yezo Group (Fig. 2), including the accretionary complexes of the unmetamorphosed Idonnappu and high-pressure metamorphosed Kamuikotan zones (Fig. 1b). The Horokanai Ophiolite and the lower part of the Sorachi Group are composed of Late Jurassic tholeiitic oceanic crust (Ishizuka, 1981; Takashima, Yoshida \& Nishi, 2002); the overlying upper Sorachi Group is represented by subaqueous calcalkaline and alkaline volcano-sedimentary sequences, suggesting an oceanic island-arc setting (Girard et al. 1991; Niida, 1992; Takashima et al. 2002). The Yezo Group conformably overlies the Sorachi Group in very thick sandstone and mudstone sequences (Takashima et al. 2004). The sandy clastics of the Yezo Group were derived from Cretaceous igneous rocks and Jurassic accretionary complexes of the Oshima Belt, a contemporaneous continental arc setting (Kito et al. 1986).

\section{Lithostratigraphy of the Late Jurassic-Early Cretaceous island-arc sequence}

The Sorachi Group represents Late Jurassic-Early Cretaceous island-arc belt sequences (Fig. 1b). The widest exposure of this group occurs in the central Sorachi-Yezo Belt, where intermittent outcrops are found in four areas from the rear of the arc (west) to the trench side (east) within a N-S-trending fold-and-thrust system. As shown in Figure 3, these areas are (1) the western Yubari Range, (2) the eastern Yubari Range, (3) Nae and (4) Nunobe. The Sorachi Group consists mainly of subaqueous volcanic and volcaniclastic rocks with minor intercalations of terrigenous clastic sediments; the group can be subdivided into four rock assemblages (Fig. 2). The basal assemblage, represented by the uppermost Jurassic Gokurakudaira Formation (Table 1), is dominated by tholeiitic basalt in all areas, as is the uppermost constituent (basalt member) of the Horokanai Ophiolite (Takashima, Yoshida \& Nishi, 2002). The overlying second and third assemblages are characterized by a predominance of trachyandesitic volcaniclastic and intrusive rocks and alkali basaltic rocks, respectively. The former assemblage dates to Berriasian times, and the latter dates to the Valanginian. The fourth assemblage, excluding in situ igneous rocks, consists mainly of tuffaceous mudstone with subordinate intercalations of trachyandesitic volcanic sandstones and terrigenous clastics. This assemblage ranges in age from Hauterivian to Barremian. The Sorachi Group is conformably covered by terrigenous turbidites and 


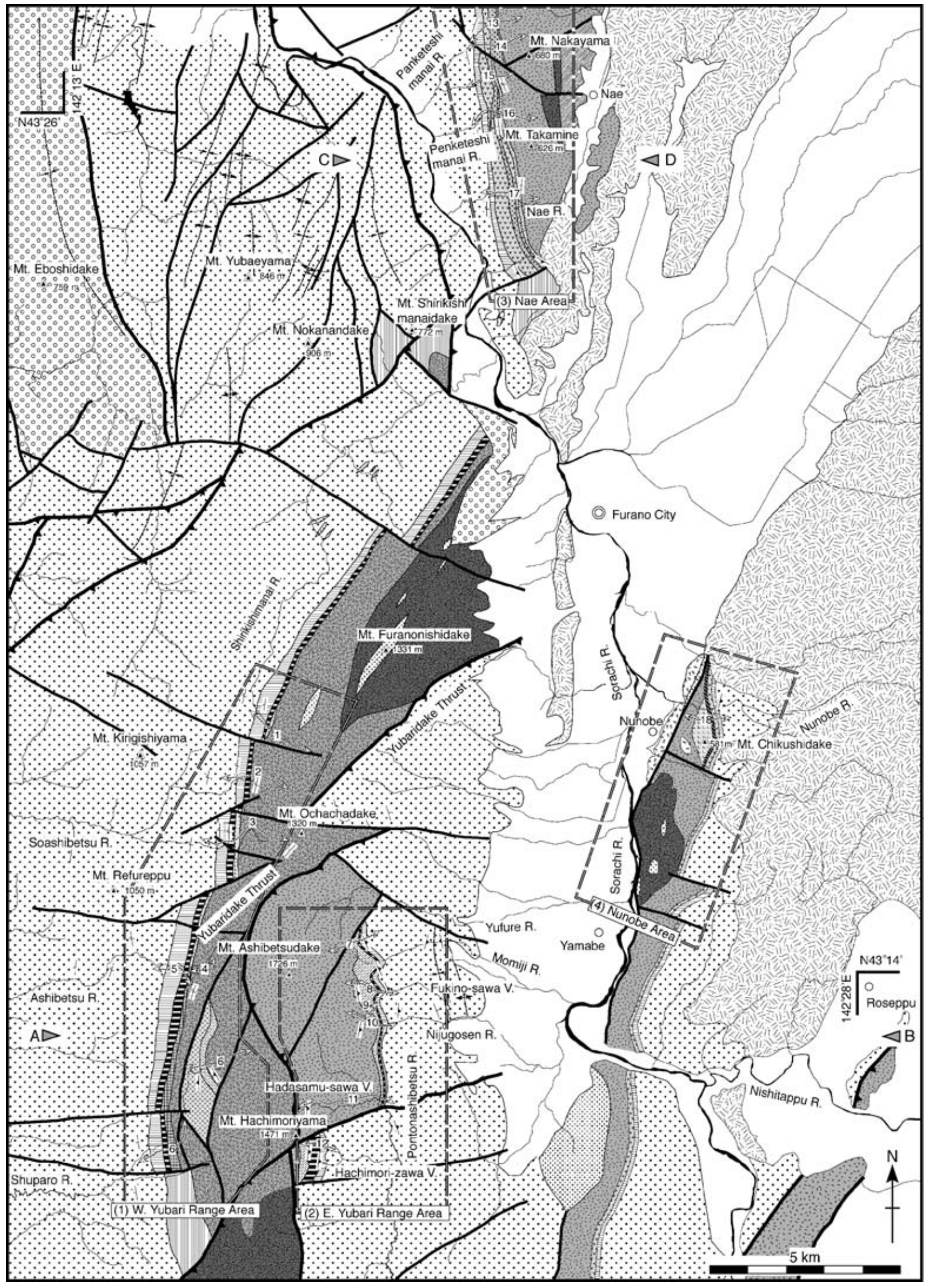

Figure 3. For legend see facing page. 


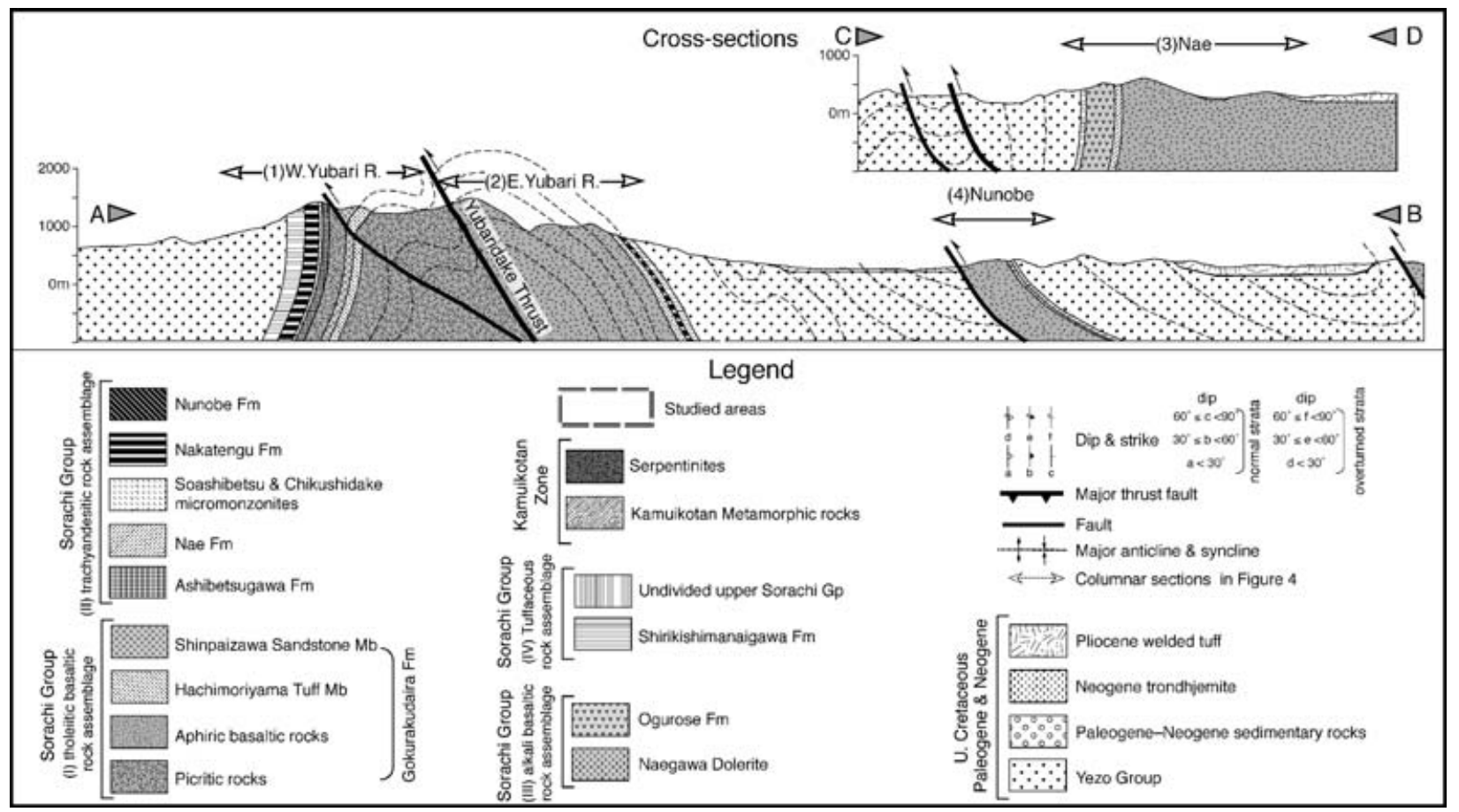

Figure 3. Geological map and structural profile sections of the central Hokkaido Island region.

Table 1. Summary of the lithostratigraphic units of the Sorachi Group

\begin{tabular}{|c|c|c|c|c|c|}
\hline Lithostratigraphic unit & Distribution & Type section & Definition & Thickness & Major lithology \\
\hline Gokurakudaira Fm. & All areas & $\begin{array}{l}\text { Mt Gokurakudaira } \\
\text { (W. Yubari Range) }\end{array}$ & $\begin{array}{l}\text { Takashima, Nishi \& } \\
\text { Yoshida (2001) }\end{array}$ & $>700 \mathrm{~m}$ & $\begin{array}{l}\text { Basaltic pillow lava and } \\
\text { hyaloclastite }\end{array}$ \\
\hline Hachimoriyama Tuff Mb. & W Yubari Range & Shuparo River & $\begin{array}{l}\text { Takashima, Nishi \& } \\
\text { Yoshida (2001) }\end{array}$ & $<190 \mathrm{~m}$ & $\begin{array}{l}\text { Tuffaceous mudstone and } \\
\text { trachyandesitic-dacitic } \\
\text { volcanic breccia }\end{array}$ \\
\hline Shinpaizawa Sandstone Mb. & W Yubari Range & Shuparo River & $\begin{array}{l}\text { Takashima, Nishi \& } \\
\text { Yoshida (2001) }\end{array}$ & $<170 \mathrm{~m}$ & $\begin{array}{l}\text { Terrigenous sandstone and } \\
\text { mudstone }\end{array}$ \\
\hline Ashibetsugawa Fm. & W Yubari Range & Ashibetsu River & $\begin{array}{l}\text { Takashima, Nishi \& } \\
\text { Yoshida (2001) }\end{array}$ & $<200 \mathrm{~m}$ & Red siliceous mudstone \\
\hline Nae Fm. & $\begin{array}{l}\text { Nae and E Yubari } \\
\text { Range }\end{array}$ & $\begin{array}{l}\text { Penketeshimanai } \\
\text { River }\end{array}$ & New & $<1300 \mathrm{~m}$ & $\begin{array}{l}\text { Pale green tuffaceous } \\
\text { mudstone }\end{array}$ \\
\hline Soashibetsu Micromonzonite & W Yubari Range & Soashibetsu River & New & - & Micromonzonite sill \\
\hline $\begin{array}{l}\text { Chikushidake } \\
\text { Micromonzonite }\end{array}$ & Nunobe & Nunobe quarry & $\begin{array}{l}\text { Takashima et al. } \\
\quad(2002)\end{array}$ & & Micromonzonite sill \\
\hline Nakatengu Fm. & $\begin{array}{l}\text { W Yubari Range and } \\
\text { E Yubari Range }\end{array}$ & Ashibetsu River & $\begin{array}{l}\text { Takashima, Nishi \& } \\
\text { Yoshida (2001) }\end{array}$ & $<330 \mathrm{~m}$ & $\begin{array}{l}\text { Trachyandesitic volcanic } \\
\text { breccia and sandstone } \\
\text { with oolitic limestones }\end{array}$ \\
\hline Nunobe Fm. & Nunobe & Nunobe quarry & $\begin{array}{l}\text { Takashima et al. } \\
\quad(2002)\end{array}$ & $120 \mathrm{~m}$ & $\begin{array}{l}\text { Volcanogenic } \\
\text { conglomerate, sandstone } \\
\text { and mudstone }\end{array}$ \\
\hline Ogurose Fm. & Nunobe and Nae & Nunobe quarry & $\begin{array}{l}\text { Takashima et al. } \\
\text { (2002) }\end{array}$ & $100-500 \mathrm{~m}$ & Basaltic pillow lava \\
\hline Naegawa Dolerite & $\mathrm{Nae}$ & Nae River & Kito (1987) & & Dolerite sill \\
\hline Shirikishimanaigawa Fm. & All areas & $\begin{array}{l}\text { Shirikishimanai } \\
\text { River }\end{array}$ & $\begin{array}{l}\text { Takashima, Nishi \& } \\
\text { Yoshida (2001) }\end{array}$ & $140-560 \mathrm{~m}$ & $\begin{array}{l}\text { Pale green tuffaceous } \\
\text { mudstone }\end{array}$ \\
\hline
\end{tabular}

Mb. - Member; Fm. - Formation

hemipelagic mudstone of the Yezo Group in all areas (Fig. 2).

\section{3.a. Tholeiitic basaltic rock assemblage (the lower Sorachi Group: Gokurakudaira Formation)}

The tholeiitic basaltic rock assemblage, represented by the Gokurakudaira Formation, is equivalent to the uppermost basaltic lava unit of the Horokanai Ophiolite
(Takashima, Nishi \& Yoshida, 2001; Takashima, Yoshida \& Nishi, 2002). Although tholeiitic basalts prevail in this assemblage, dacitic-trachyandesitic volcaniclastic rocks and terrigenous sediments are intercalated in the western Yubari Range area (Fig. 4, column 6); these members are referred to as the Hachimoriyama Tuff and Shinpaizawa Sandstone, respectively (Takashima, Nishi \& Yoshida, 2001). 


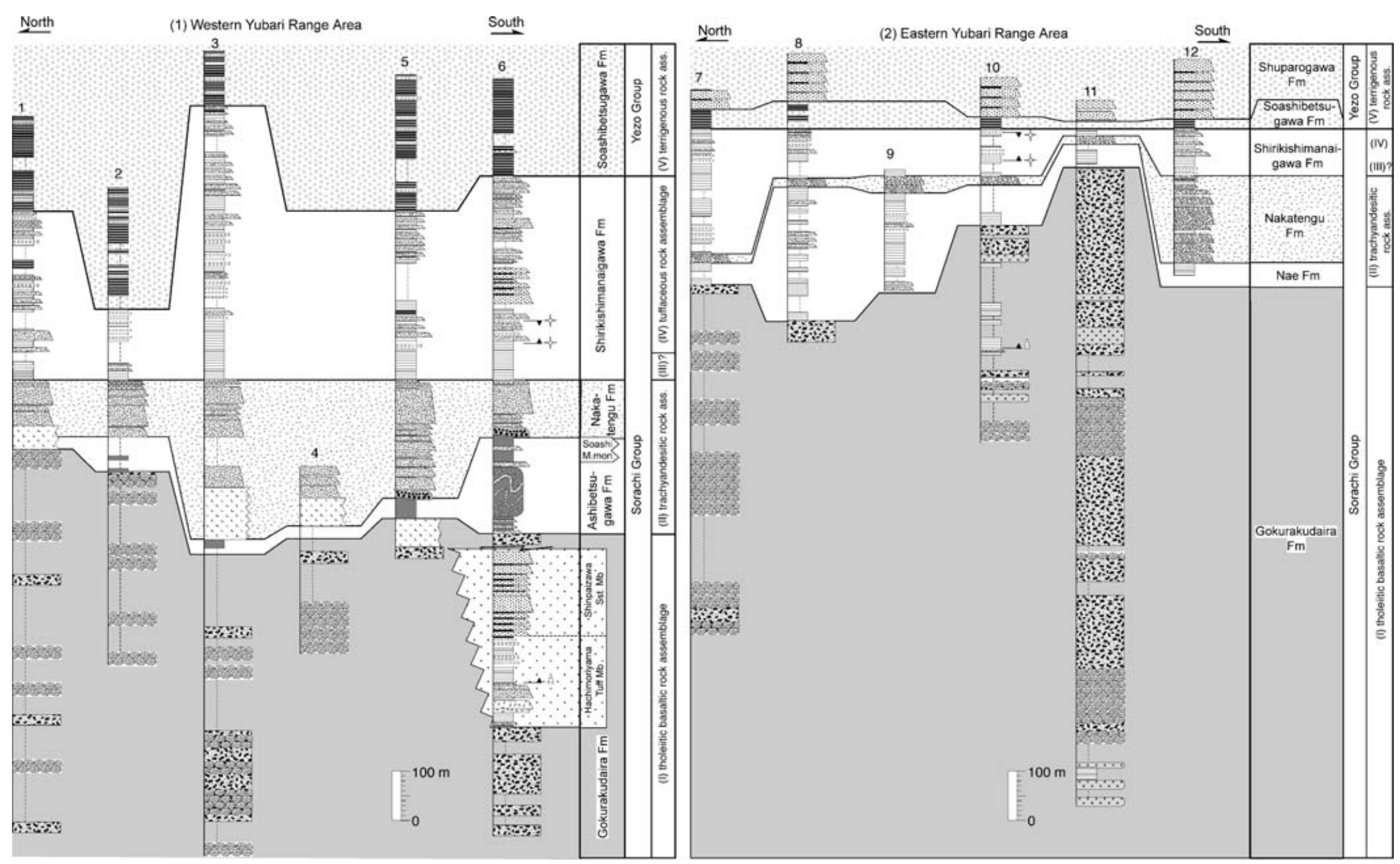




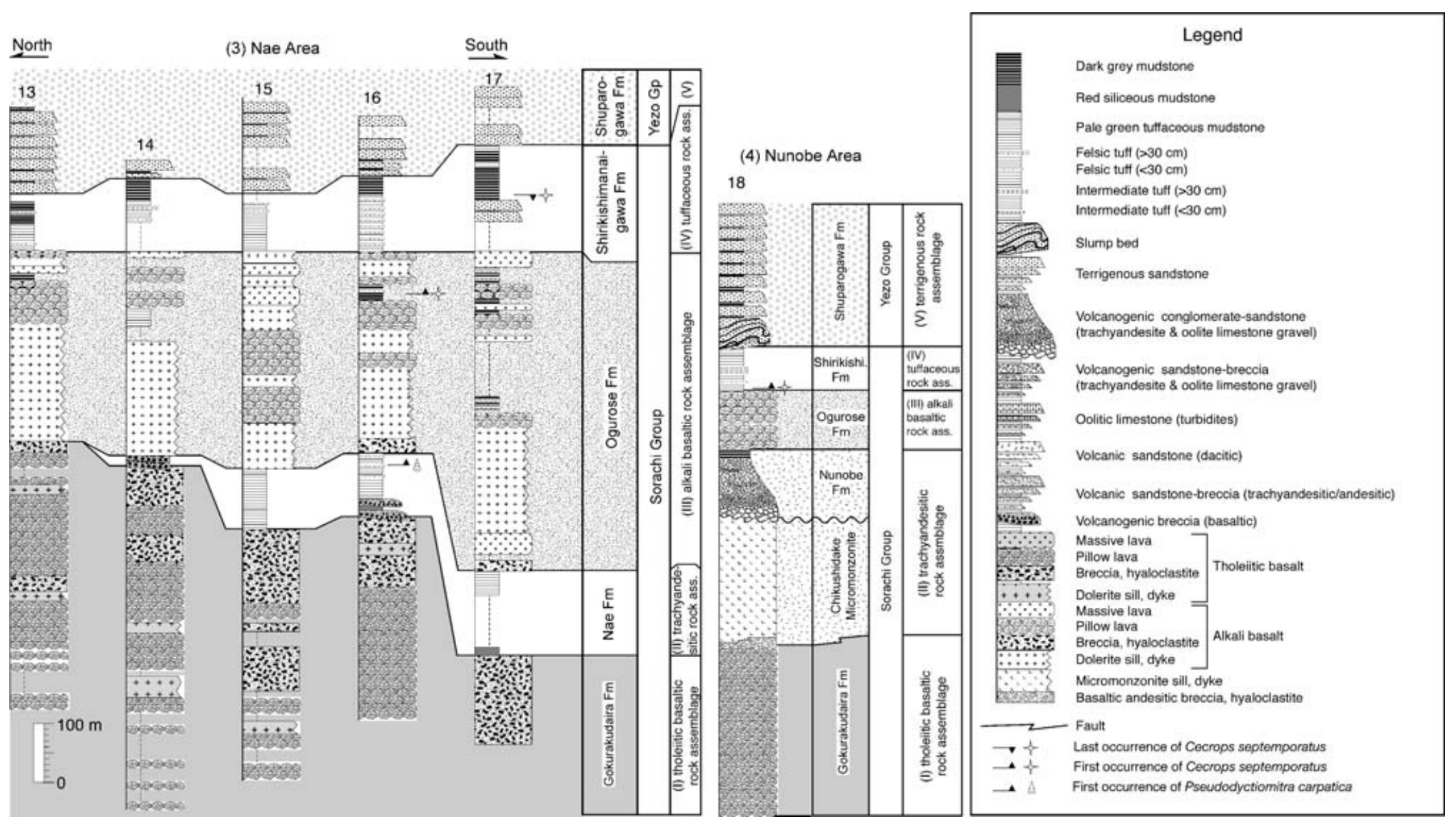

Figure 4. Correlation of selected columnar sections from the study areas. 1-6 - western Yubari Range area. 1 - Shirikishimanai River; 2 - northern Soashibetsu River; 3 - Soashibetsu River; 4 northern Ashibetsu River; 5 - Ashibetsu River; 6 - Shuparo River. 7-12 - eastern Yubari Range area. 7 - Ashibetsudake new trail; 8 - Fukino-sawa Valley; 9 - northern Nijugosen River; 10 Nijugosen River; 11 - Hadasamu-zawa Valley; 12 - Hachimori-zawa Valley. 13-17 - Nae area. 13 - northern Panketeshimanai River; 14 - Panketeshimanai River; 15 - southern Panketeshimanai River; 16 - Penketeshimanai River; 17 - Nae River. 18 - Nunobe area, Nunobe Quarry. 
Table 2. Petrographic summary of the igneous rocks of the Sorachi Group

\begin{tabular}{|c|c|c|c|}
\hline Lithostratigraphic unit & Rock type & Phenocryst & Groundmass (texture) \\
\hline \multirow[t]{3}{*}{ Gokurakudaira Fm. } & Aphyric basalt & & $\mathrm{Pl} \geq \mathrm{cpx}>$ opq, (intergranular) \\
\hline & Picrite & $\mathrm{Ol}(30-70 \%)>\operatorname{sp}(<1 \%)$ & $\mathrm{Cpx}>\mathrm{pl}>\mathrm{sp},($ dendrite $)$ \\
\hline & Olivine basaltic andesite & $\mathrm{Ol}(3-20 \%)>\operatorname{sp}(<1 \%)$ & Glass \\
\hline \multirow[t]{2}{*}{ Hachimoriyama Tuff Mb. } & Trachyandesite fragments & $\mathrm{P} 1 \gg \mathrm{cpx}^{*}$ & Glass $>$ pl $>$ opq, (intersertal / hyalopilitic) \\
\hline & $\begin{array}{l}\text { of vol. bre. } \\
\text { Dacite fragments of vol. sst. }\end{array}$ & $\mathrm{Pl}>\mathrm{qz}>\mathrm{cpx}^{*}$ & Glass $\gg \mathrm{pl}>\mathrm{qz}>$ opq, (hyalopilitic) \\
\hline Ashibetsugawa Fm. & $\begin{array}{l}\text { Andesite fragments } \\
\text { of vol. sst. }\end{array}$ & $\mathrm{Pl}>\mathrm{cpx}>\mathrm{qz}^{*}$ & $\mathrm{Pl}>$ glass $>$ opq, $($ intersertal $)$ \\
\hline Nae Fm. & $\begin{array}{l}\text { Trachyandesite fragments } \\
\text { of vol. sst. }\end{array}$ & $\mathrm{P} 1>\mathrm{cpx}^{*}$ & Glass $>$ pl $>$ opq \\
\hline \multirow[t]{3}{*}{ Nakatengu Fm. } & Aphyric basalt gravel & & $\mathrm{Pl}>\mathrm{cpx}>$ opq, (intergranular) \\
\hline & Picrite gravel & $\mathrm{Ol}(20-50 \%)$ & Cpx $>$ glass \\
\hline & $\begin{array}{l}\text { Trachyandesite fragments } \\
\text { of vol. bre. }\end{array}$ & $\mathrm{Pl} \gg \mathrm{cpx} \gg \mathrm{opq}^{*}$ & $\mathrm{Pl}>$ glass $>$ opq, $($ intersertal $)$ \\
\hline Nunobe Fm. & Trachyandesite gravel & $\begin{array}{l}\mathrm{Pl}(20-50 \%)>\operatorname{cpx}(1-10 \%) \\
>\text { opq }(0-5 \%)\end{array}$ & Glass $\gg p l>o p q$ \\
\hline Soashibetsu Micromonzonite & Micromonzonite & & $\mathrm{Pl} \gg \mathrm{opq}>\mathrm{qz}>\mathrm{hbl}>\mathrm{cpx}$ \\
\hline Chikushidake Micromonzonite & Micromonzonite & & $\mathrm{Pl} \gg \mathrm{cpx}>\mathrm{opq}>\mathrm{hbl}>\mathrm{kf}$ \\
\hline Ogurose Fm. & Aphyric basalt & $\operatorname{Pl}(0-5 \%)>\operatorname{cpx}(0-2 \%)$ & $\mathrm{Pl}>\mathrm{cpx}>\mathrm{opq}$, (intergranular) \\
\hline Naegawa Dolerite & Dolerite & & $\mathrm{Pl}>\mathrm{cpx}>$ opq, (ophitic) \\
\hline Shirikishimanaigawa Fm. & $\begin{array}{l}\text { Trachyandesite fragments } \\
\text { of vol. sst. }\end{array}$ & $\mathrm{Pl}>\mathrm{cpx}>\mathrm{opq}^{*}$ & Glass $\gg \mathrm{pl} \gg \mathrm{opq}$ \\
\hline
\end{tabular}

vol. - volcanic; sst. - sandstone; bre. - breccia; ol - olivine; sp - spinel; cpx - clinopyroxene; pl - plagioclase; qz - quartz; opq - opaque mineral; hbl - hornblende; $\mathrm{kf}$ - alkali feldspar. * Proportions were not measured because of small area of rock fragments.

\section{3.a.1. Gokurakudaira Formation}

The volcanic rocks of the Gokurakudaira Formation consist of basaltic pillow lava and hyaloclastite with minor intercalations of thin siliceous mudstone. The pillows are closely packed and fitted together and range in width from 30 to $80 \mathrm{~cm}$ (Fig. 5a). The hyaloclastites consist of rubble smaller than $60 \mathrm{~cm}$ across and a fine-grained matrix composed of glass shards. The basalts are divided into two rock types: the aphyric type, distributed in the eastern Yubari Range, Nae and Nunobe areas (Fig. 6a), and the picritic type, distributed in the western Yubari Range area (Fig. 6b). The aphyric basalt consists of idiomorphic plagioclase, granular clinopyroxene and opaque minerals (Table 2), while the picritic basalt consists mainly of olivine and clinopyroxene with lesser amounts of plagioclase and spinel (Table 2). Olivine-phyric basaltic andesites occur at the top of the formation in the Nunobe area (Fig. 4). The andesites consist of idiomorphic phenocrysts of olivine and glassy groundmass (Table 2).

Takashima et al. (2002) noted that the basalts of this formation resemble the tholeiitic basalts of the back-arc basin based on whole-rock major and trace element geochemistry and the chemical compositions of olivine-spinel minerals.

\section{3.a.2. Hachimoriyama Tuff Member}

The Hachimoriyama Tuff Member is a volcanosedimentary succession dominated by pale green tuffaceous mudstone with intercalations of dacitictrachyandesitic volcaniclastic rocks (Fig. 4, column 6). The pale green tuffaceous mudstone conformably cov- ers the basaltic breccia of the Gokurakudaira Formation. The mudstone exhibits medium bedding and contains abundant radiolarian fossils. This member intercalates a $50 \mathrm{~m}$ thick unit consisting of dacitic and trachyandesitic volcaniclastic breccia-sandstone beds. Each volcaniclastic bed has a sharp, erosional base and a flat top showing the $\mathrm{S}_{3}-\mathrm{T}_{\mathrm{b}-\mathrm{d}}$ sequence described by Lowe (1982). The dacitic volcanic sandstone beds are $0.3-2 \mathrm{~m}$ thick and consist of corroded quartz and dacite fragments (Table 2), admixed with subordinate amounts of idiomorphic plagioclase, clinopyroxene, opaque minerals and pumice, in order of decreasing abundance. The trachyandesitic breccia and sandstone beds are usually 0.3 to $4 \mathrm{~m}$ thick and made of plagioclase-phyric trachyandesite fragments (Table 2), idiomorphic plagioclase and clinopyroxene, in order of decreasing abundance.

\section{3.a.3. Shinpaizawa Sandstone Member}

Sandstone dominates the Shinpaizawa Sandstone Member and alternates with beds of blue-grey sandstone and dark grey mudstone (Fig. 5b), both of which contain abundant plant fragments. The sandstone beds also exhibit the $\mathrm{S}_{1}-\mathrm{T}_{\mathrm{b}-\mathrm{e}}$ sequence described by Lowe (1982) and are composed of well-sorted and medium- to coarse-grained lithic or feldspathic arenite, consisting mainly of detrital quartz and feldspar (smaller than $2 \mathrm{~mm}$ ), with subordinate amounts of rock fragments, plants, biotite, microcline, muscovite and zircon. The rock fragments are mainly rhyolite, granite, and spherulite of rhyolite, with very small amounts of muscovite-quartz schist and hornfels exhibiting a granoblastic texture. 

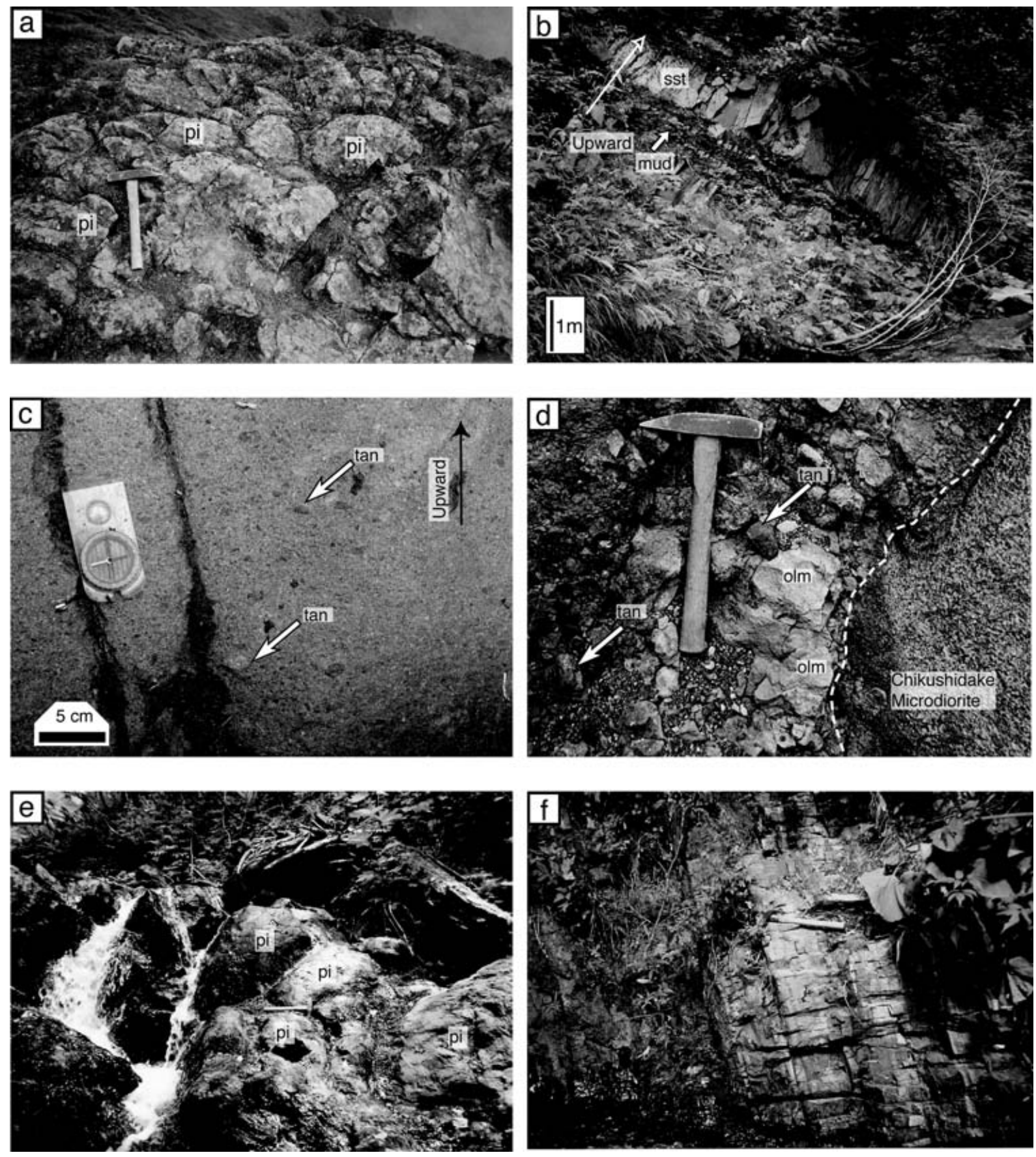

Figure 5. Photographs of the representative lithofacies of the Sorachi Group. Hammer length $=0.3 \mathrm{~m}$. a - basaltic pillow lava; Gokurakudaira Formation, Mt Ashibetsudake, eastern Yubari Range area. b - terrigenous sandstone beds; Shinpaizawa Sandstone Member, Shuparo River, western Yubari Range area. c - trachyandesitic breccia; Nakatengu Formation, Ashibetsu River, western Yubari Range area. d - unconformable contact between the Chikushidake Micromonzonite and basal conglomerate of the Nunobe Formation, Nunobe quarry, Nunobe area. e - basaltic pillow lava; Ogurose Formation, Panketeshimanai River, Nae area. $\mathrm{f}$ - pale green tuffaceous mudstone; Shirikishimanaigawa Formation, Shuparo River, western Yubari Range area. Pi - pillow lobe; tan trachyandesite.

3.b. Trachyandesitic rock assemblage (lower part of the Upper Sorachi Group: the Ashibetsugawa, Nae, Nakatengu and Nunobe formations and the Soashibetsu and Chikushidake micromonzonites)

The trachyandesitic rock assemblage is characterized by a major occurrence of trachyandesitic volcaniclastic and intrusive rocks with minor oolitic limestones. The lower part of this assemblage is dominated by mudstone represented by the Ashibetsugawa and Nae formations, while very thick trachyandesitic volcaniclastic rocks and micromonzonite prevail in the upper part represented by the Nakatengu and Nunobe formations and the Soashibetsu and Chikushidake micromonzonites. 


\section{3.b.1. Ashibetsugawa Formation}

The Ashibetsugawa Formation, distributed only in the western Yubari Range (Fig. 4, columns 1-6), is comprised of red siliceous mudstone and occasionally intercalates with medium- to thick-bedded trachyandesitic or andesitic volcanic sandstones. The red siliceous mudstone of this formation conformably overlies the basaltic rocks of the Gokurakudaira Formation. The mudstone exhibits medium bedding, occasionally accompanied by thin beds of pale green mudstone. These mudstones have few trace fossils but many radiolarian fossils. The intercalated trachyandesitic/andesitic volcanic sandstones are dark grey to bottle green in colour and are turbidites showing the $\mathrm{S}_{3}-\mathrm{T}_{\mathrm{b}-\mathrm{c}}$ divisions of Lowe (1982). These sandstones contain poorly sorted lithic arenite, consisting mainly of trachyandesite or andesitic fragments (Table 2) with subordinate amounts of pumice, clinopyroxene, plagioclase, corroded quartz, opaque minerals and hornblende.

\section{3.b.2. Nae Formation}

The Nae Formation, distributed in the eastern Yubari Range and Nae areas (Fig. 4, columns 7-17), is represented by pale green to blue-green tuffaceous mudstone that intercalates with felsic-intermediate tuff and trachyandesitic or andesitic volcanic sandstone beds. The tuffaceous mudstone of this formation conformably covers the basalts of the Gokurakudaira Formation in both areas. The pale green tuffaceous mudstone beds are medium bedded and contain abundant radiolarian fossils. The porous, soft and pale green felsicintermediate tuff beds, which are intercalated frequently in the middle part of this formation, are 5 to $20 \mathrm{~cm}$ thick.

\section{3.b.3. Nakatengu Formation}

The Nakatengu Formation, distributed in the western and eastern Yubari Range areas, is defined by a predominance of thick beds of trachyandesitic volcaniclastic breccias. The formation conformably overlies the Ashibetsugawa or Nae formations. Although this formation is distributed in both the western and eastern Yubari Range areas, the lithology differs slightly between these two areas. The trachyandesitic breccias in the western Yubari Range area do not include exotic fragments and have an E-to-W palaeocurrent direction, while those in the eastern Yubari Range area contain ample oolite limestone rubble and exhibit a W-to-E palaeocurrent direction.

3.b.3.a. Western Yubari Range area. The Nakatengu Formation in the western Yubari Range area conformably overlies the red mudstone of the Ashibetsugawa Formation and consists mainly of trachyandesitic breccias-sandstones with one to seven intercalations of oolite limestone beds at the top (Fig. 4, columns 16). Basaltic breccias occur locally at the base of this formation (Fig. 4, columns 5-6).

The resedimented basaltic breccia intercalated at the base of this formation is thick- to very thickbedded $(0.3-4 \mathrm{~m})$, consisting of massive, ungraded lower portions and thinner, normally graded tops. Subangular to subrounded fragments of basalt and dolerite of boulder to granule sizes are contained in a red granule matrix. The basalt fragments are similar to those of the Gokurakudaira Formation, consisting mainly of aphyric basalt with minor picrite.

Trachyandesitic volcaniclastic breccia and sandstone are the major components of this formation (Fig. 5c). The breccias have well-developed stratification. Bed thickness ranges from 2 to $10 \mathrm{~m}$, with the thickest reaching $50 \mathrm{~m}$. These beds of poorly sorted lithic rudaceous arenite are bluish-green in colour, and are composed mainly of trachyandesite rubble (smaller than $2 \mathrm{~cm}$; Table 2), idiomorphic plagioclase grains and pumice, with subordinate amounts of idiomorphic clinopyroxene grains and rip-up clasts of red or pale green mudstone (Fig. 6c). The fabric of the rip-up clast indicates that the palaeocurrent of the breccias was roughly $\mathrm{E}$ to $\mathrm{W}$.

Stratified grey oolite limestones are intercalated at the top of this formation. These limestones consist mainly of ooids ( $70-95 \%$ in volume), with subordinate amounts of trachyandesite fragments, mineral grains and fossils (benthic foraminifera, fragments of coral, algae, echinoids and bivalves), in order of decreasing abundance (Fig. 6d). The trachyandesite fragments are similar to those of the underlying breccia beds. The limestone beds range in thickness from 0.05 to $2.7 \mathrm{~m}$ and are turbidites exhibiting the $\mathrm{T}_{\mathrm{b}-\mathrm{d}}$ divisions of Lowe (1982).

3.b.3.b. Eastern Yubari Range area. The Nakatengu Formation in the Eastern Yubari Range area conformably covers the pale green tuffaceous mudstone of the Nae Formation. This formation is represented by several beds of resedimented breccia (Fig. 4, columns 7-12) ranging in thickness from 1 to $4 \mathrm{~m}$, and exhibiting the $\mathrm{R}_{3}-\mathrm{S}_{1}$ divisions of a high-density turbidite (Lowe, 1982). Angular to subangular fragments of blue-grey trachyandesite and subordinate amounts of grey oolitic limestone of boulder to granule size are contained in a grey matrix made of mineral grains, ooids and small fragments of trachyandesite. Microscopic observations have revealed that these trachyandesite gravels are plagioclase-clinopyroxene phyric trachyandesite (Table 2). The fabric of rudites roughly indicates palaeocurrent directions from $\mathrm{W}$ to $\mathrm{E}$; this directional trend is opposite that of the Nakatengu Formation in the western Yubari Range area. 


\section{3.b.4. Soashibetsu Micromonzonites}

Micromonzonite sheets intrude into strata lower than the Nakatengu Formation and attain a maximum thickness of $100 \mathrm{~m}$ in the Soashibetsu River section (Figs 3, 4, columns 1-5). These holocrystalline sheets exhibit intergranular texture and are composed of idiomorphic plagioclase, with minor amounts of granular opaque minerals, allotriomorphic quartz, hornblende and granular zircon, in order of decreasing abundance (Table 2). The major and trace compositions of the microdiorites are closely related to those of the trachyandesite fragments of the Nakatengu Formation.

\section{3.b.5. Chikushidake Micromonzonite}

The Chikushidake Micromonzonite is distributed only in the northern part of the Nunobe area and intrudes into the Gokurakudaira Formation in a $\mathrm{N}-\mathrm{S}$ direction (Figs 3, 4, columns 4-18). The micromonzonite, unconformably overlain by the basal conglomerate of the Nunobe Formation, is grey to greenish-grey in colour and $220 \mathrm{~m}$ thick. The lateral extent can be traced meridionally for $1700 \mathrm{~m}$. The micromonzonite is comprised of idiomorphic plagioclase and subordinate amounts of granular clinopyroxene, granular opaque minerals and allotriomorphic hornblende, in order of decreasing abundance (Table 2; Fig. 6e).

\section{3.b.6. Nunobe Formation}

This formation, distributed only in the Nunobe area, unconformably overlies the Chikushidake Micromonzonite and exhibits an upward-fining lithology from clastsupported basal conglomerate through sandstone to mudstone (Fig. 4, column 18).

The basal conglomerate overlies the Chikushidake Micromonzonite with irregular contacts (Fig. 5d), and is comprised of subrounded to rounded gravels. This conglomerate is clast supported, poorly sorted and structureless. The gravels consist mainly of plagioclase-clinopyroxene-phyric trachyandesite, with minor amounts of micromonzonite, oolite limestone, red-pale green mudstone and trachyandesitic volcaniclastic sandstone, in order of decreasing abundance. Gravels are generally $5-20 \mathrm{~cm}$ in the basal part and decreasing in size upwards. In the basal portion, this conglomerate occasionally contains large (1 to $3 \mathrm{~m}$ in size) blocks of oolite limestone. The oolitic limestone in the gravels is composed mainly of ooids with diameters of 1 to $4 \mathrm{~mm}$ and containing benthic foraminifera, gastropods, coral and bivalves, as well as fragments of the above-mentioned trachyandesite and some crystal grains derived from trachyandesite.

The conglomerate grades into laminated greenish/dark grey mudstone at a horizon approximately $87 \mathrm{~m}$ above the base through sandstone. The mudstone contains few radiolarian fossils. 3.c. Alkali basaltic rocks assemblage (middle part of the Upper Sorachi Group: the Ogurose Formation)

This rock assemblage is represented by the alkali basaltic rocks of the Ogurose Formation and the Naegawa dolerite and is distributed in the Nae and Nunobe areas (Fig. 4, columns 13-18).

\section{3.c.1. Ogurose Formation}

This formation consists mainly of pillow basalt with small amounts of basaltic breccia and mudstone. The pillow lobes are $0.5-1.50 \mathrm{~m}$ and contain vesicles (Fig. 5e). The pillow lobes of this formation are distinguishable from those of the Gokurakudaira Formation by their larger size and vesicles. The breccias consist mainly of bottle-green basalt and dolerite rubble mixed with subordinate amounts of reddish, finegrained matrix. The basalts are aphyric and consist of plagioclase, clinopyroxene and opaque minerals (Table 2); chemical analysis has revealed that these basalts are low- $\mathrm{K}_{2} \mathrm{O}$-type alkali basalt (Niida, 1992).

The intercalated mudstones can be classified into the following two types: a pale green to grey tuffaceous mudstone and a dark-grey coloured mudstone containing plant fragments.

\section{3.c.2. Naegawa dolerite sheet}

The Naegawa dolerite sheet is intruded within various horizons of the Ogurose Formation in the Nae area. The sheet extends a distance of $7 \mathrm{~km}$ in a N-S direction and is approximately $200 \mathrm{~m}$ thick (Fig. 3). These dolerites have an ophitic texture and consist mainly of hypidiomorphic clinopyroxene and idiomorphic plagioclase with lesser amounts of hypidiomorphic to granular opaque minerals and allotrimorphic hornblende, in order of decreasing abundance (Table 2; Fig. 6f). Chemical analysis of the major bulk rocks shows a correspondence to low- $\mathrm{K}_{2} \mathrm{O}$-type alkali basalts (Niida, 1992), similar to the pillow lava of the Ogurose Formation.

\section{3.d. Tuffaceous mudstone rocks assemblage (upper part of the Upper Sorachi Group: the Shirikishimanaigawa Formation)}

Represented by the Shirikishimanaigawa Formation, this rock assemblage is marked by the predominance of tuffaceous mudstone and the lack of in situ igneous rocks in the Sorachi-Yezo Belt.

\section{3.d.1. Shirikishimanaigawa Formation}

The Shirikishimanaigawa Formation covers the trachyandesitic rock assemblage in the western and eastern Yubari Range areas directly (Fig. 4, columns 1-12) and overlies the alkali basaltic rock assemblage in the Nae and Nunobe areas (Fig. 4, columns 13-18). 

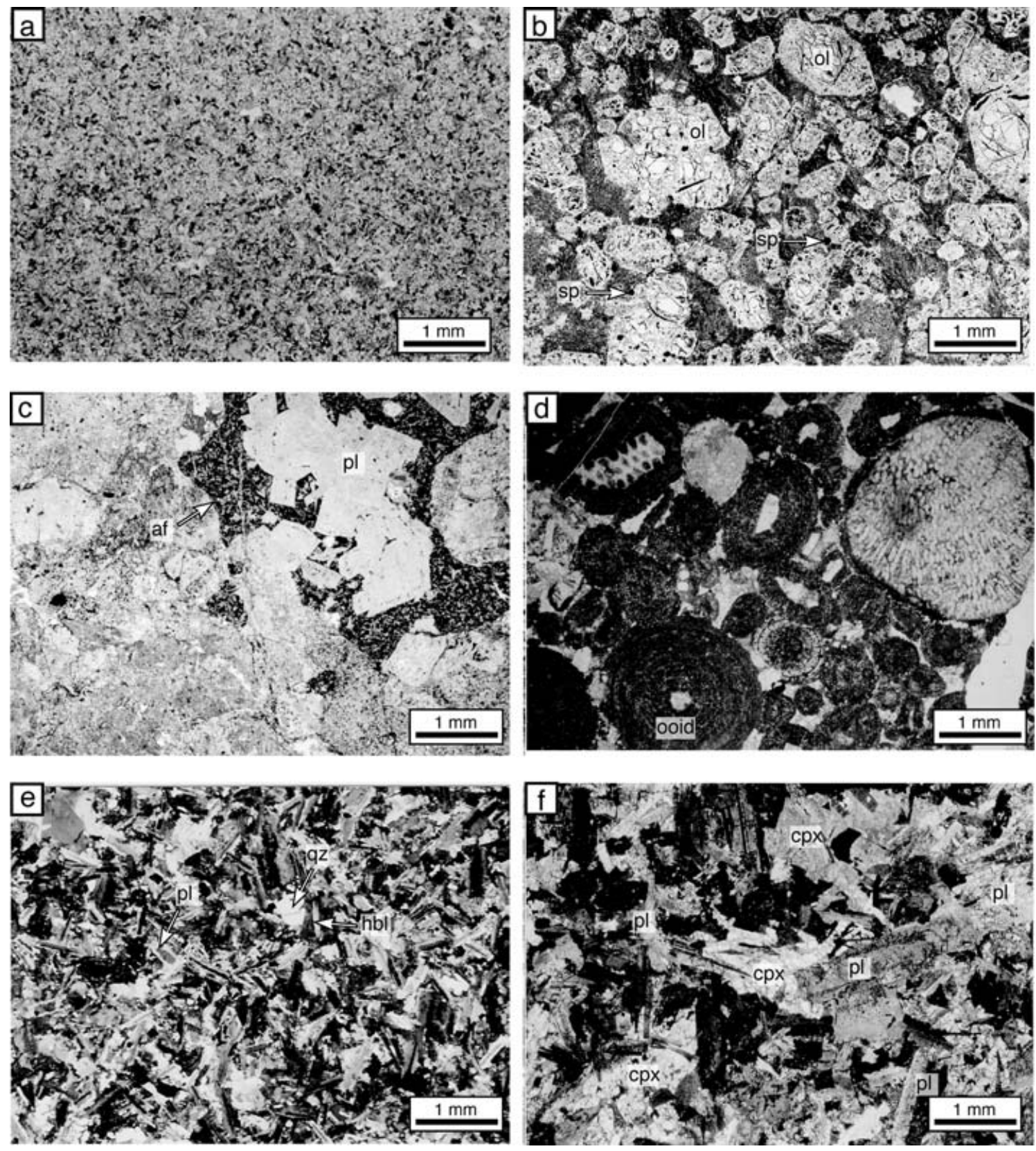

Figure 6. Microscopic photograph of representative rocks of the Sorachi Group. a - aphyric basalt (plane polarized light); Gokurakudaira Formation, Panketeshimanai River, Nae area. b - picrite (plane polarized light); Gokurakudaira Formation, Soashibetsu River, western Yubari Range area. c - trachyandesitic volcanic breccia (plane polarized light); Nakatengu Formation, Shuparo River, western Yubari Range area. d - oolite limestone (plane polarized light); Nakatengu Formation, Ashibetsu River, western Yubari Range area. e micromonzonite (crossed polars); Chikushidake Micromonzonite, Nunobe River, Nunobe area. f - dolerite (crossed nicols); Naegawa Dolerite, Panketeshimanai River, Nae area. Ol - olivine; sp - spinel; af - trachyandesite fragment; bt - biotite; pl - plagioclase; $\mathrm{qz}$ quartz; cpx - clinopyroxene; hbl - hornblende.

Although this formation is mainly made up of pale green tuffaceous mudstone and felsic tuffs, andesitic volcanic, calcareous and terrigenous turbidite sandstone beds occur in the upper part. Their palaeo-current direction is from NE to SW.

The pale green tuffaceous mudstones are usually medium-bedded and contain abundant radiolarian fossils (Fig. 5f). The mudstone is frequently intercalated with felsic tuff beds ranging from $10 \mathrm{~cm}$ to $1 \mathrm{~m}$ in thickness.
The andesitic volcanic sandstones are frequently intercalated in the upper part of this formation in the western and eastern Yubari Range areas (Fig. 4, columns 1-12). The sandstones are poorly sorted lithic arenite, consisting mainly of idiomorphic plagioclase and corroded quartz with subordinate amounts of andesite fragments (Table 2), clinopyroxene, hornblende and pumice. The volcanic sandstones are generally 10 to $30 \mathrm{~cm}$ thick and exhibit well-developed stratifications and graded bedding. 
Terrigenous sandstone beds and dark grey mudstones occur in the southern part of the western Yubari Range and Nae areas (Fig. 4, columns 5-6, 13-17). These sandstone beds are blue-grey in colour and range in thickness from 0.3 to $2 \mathrm{~m}$. They are mediumgrained and well-sorted quartz arenite, consisting of rounded quartz, feldspar, wood fragments, opaque minerals, microcline and zircon, in order of decreasing abundance.

\section{Radiolarian biostratigraphy of the Sorachi Group}

The Sorachi Group contains numerous well-preserved radiolarian fossils, as detailed by a number of radiolarian biostratigraphic studies (Kito, 1987, 1995; Kito et al. 1986; Minoura et al. 1982; Okada et al. 1991; Takashima, Nishi \& Yoshida, 2001). From examining various areas in Hokkaido, these studies have identified three datum planes within the Sorachi Group. In ascending order, these planes are represented by the first occurrence of Pseudodictyomitra carpatica, the first occurrence of Cecrops septemporatus and the last occurrence of C. septemporatus (e.g. Kito, 1987, 1995; Takashima, Nishi \& Yoshida, 2001). These planes correlate to Kimmeridgian-Tithonian, Late Valanginian and Early Barremian times, respectively (Baumgartner et al. 1995).

Figures 2 and 4 illustrate the three datum planes. The first occurrence of $P$. carpatica coincides with the middle of the Hachimoriyama Tuff Member in the western Yubari Range, the lower Nae Formation in the eastern Yubari Range area and the upper Nae Formation in the Nae area. The first occurrence of C. septemporatus is associated with the lower part of the Shirikishimanaigawa Formation in the western and eastern Yubari Range and Nunobe areas, as well as with the upper Ogurose Formation in the Nae area. The last occurrence of $C$. septemporatus was identified in the middle to upper Shirikishimanaigawa Formation in all areas. The basal part of the Yezo Group was correlated with the lower Aptian, based on the integrated stratigraphy of planktonic foraminifera, radiolaria and carbon isotope ratios (Ando et al. 2002, 2003; Takashima et al. 2004).

According to the above data, the four rock assemblages of the Sorachi Group (tholeiitic basaltic rock, trachyandesitic rock, alkali basaltic rock and tuffaceous rock assemblages, in ascending order) were correlated with Kimmeridgian-Tithonian, Berriasian, Valanginian and Hauterivian-Barremian, respectively.

\section{Discussion: Late Jurassic-Early Cretaceous geodynamic evolution of the eastern Asian continental margin}

The Early Cretaceous reconstruction map shown in Figure 7 was based on the palaeomap by Tazawa (2004) and Sakashima et al. (2003), considering the

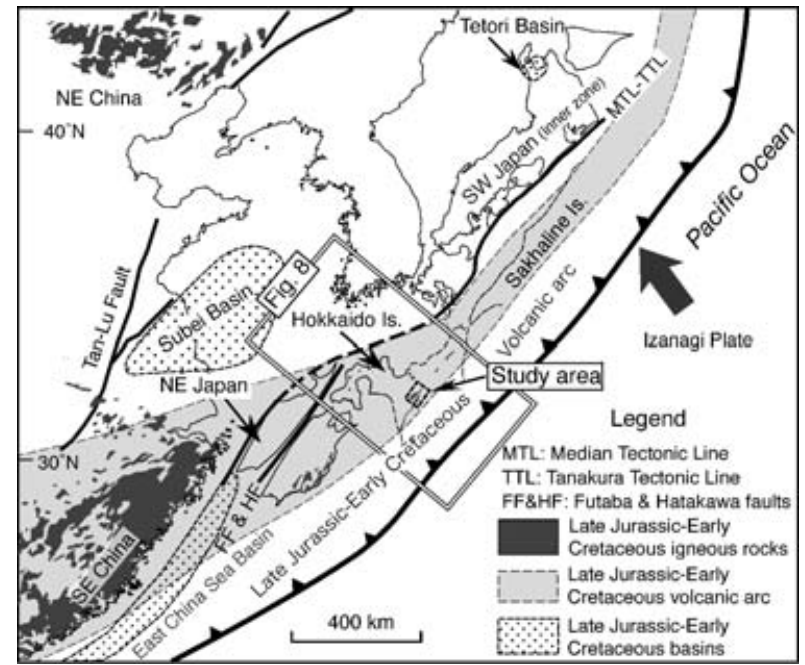

Figure 7. Early Cretaceous reconstruction map of the eastern Asia.

palaeomagnetic reconstructions of the $\mathrm{N}-\mathrm{S}$ China Block (Enkin et al. 1991; Kirillova, 2003b; Meng, 2003; Ren et al. 2002; Zorin, 1999). The Valanginian palaeolatitude of $31.5^{\circ} \mathrm{N} \pm 5^{\circ}$ in the Nae area, derived from the palaeomagnetic data of the Naegawa dolerite (Hoshi \& Takashima, 1999), coincided with the relative position on this palaeomap. The Sorachi Group is thought to have formed along a series of volcanic zones that extended from southeastern China. Based on combined lithostratigraphic and biostratigraphic correlations, the volcanic and sedimentary phases represented by the Sorachi Group can be divided into four stages, as outlined below (Fig. 8).

\section{5.a. Stage I (Kimmeridgian-Tithonian: sea-floor spreading)}

This stage was characterized by a predominance of BABB (back-arc basin basalt)-like tholeiitic basalts, represented by the Gokurakudaira Formation (e.g. Takashima, Yoshida \& Nishi, 2002). The terrigenous and dacitic-trachyandesitic volcaniclastic turbidites supplied from the Asian continental margin were deposited only in the western Yubari Range area (Fig. 8, a.1). Takashima, Yoshida \& Nishi (2002) subdivided this period into three stages: (1) rifting along the forearc, (2) sea-floor spreading and (3) post-spreading based on the petrological data of the Gokurakudaira Formation.

According to Okada (1999), extensive rift basins, such as the East China Sea and Subei and Tetori basins, formed along the eastern margin of the Asian continent during this period (Fig. 7). Furthermore, contemporaneous continental extension accompanied by a large amount of volcanism occurred in SE China (e.g. Li et al. 2004; Jiang et al. 2005), NE China (Ren et al. 2002; Meng, 2003) and SE Russia (Kirillova, 2003a,b). Based on the geochemical and 

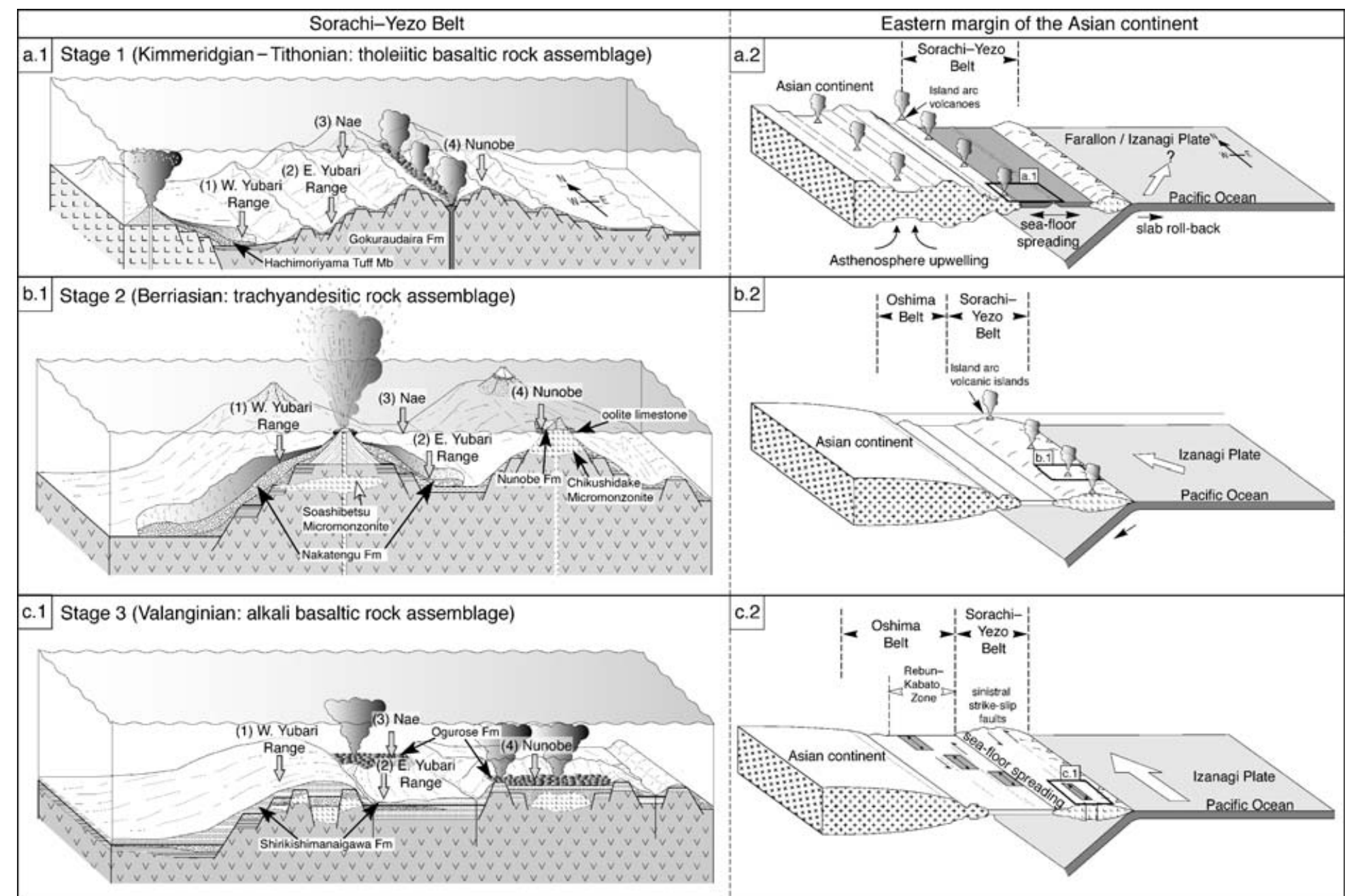

Legend (a.1 -c.1)

- Oolite limestone

Andesitic trachyandesitic volcano

Basaltic pillow lava

(Gokurakudaira \& Ogurose Fms) Andesitic/ trachyandesitic pyroclast flow (HachimoriyamaTut Mb

Nakatengu Fm, W. Yubari Ran

Fre. Trachyandesitic debris flow
(Nakatengu Fm. E. Yubari Range)

Chikushidake \& Soashibetsu

Micromonzonites

ㄱ... Pale green tuffaceous mudstone

Red tuttaceous mudstone

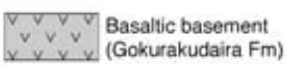

\section{Legend (a.2-c.2)}

9 Active telsic-intermediate
volcanism
Island arc crust

Continental crust

Old oceanic crust

Young oceanic crust

Trench

Figure 8. Schematic geodynamic evolution models during the Late Jurassic to Early Cretaceous interval. (1) Sorachi-Yezo Belt; (2) eastern margin of the Asian continent. 
isotopic signatures of the upper Jurassic igneous rocks, these regions are thought to have experienced rapid lithospheric extension and thinning, associated with the geothermal elevation due to upwelling of the asthenosphere (Sewell \& Campbell, 1997; Meng, 2003; Li et al. 2004).

The oceanic plate stratigraphy reconstructed from the Mesozoic accretionary complex in Hokkaido (Oshima Belt and Kamuikotan Zone) indicates that the subducting Pacific oceanic plate (probably the Farallon and/or Izanagi plates) was c. 100-140 million years old during the Jurassic-Early Cretaceous period (e.g. Ueda \& Miyashita, 2005). This age is considered to be old enough to cause trench roll-back (Molnar \& Atwater, 1978). Contemporaneous relative motion of the Farallon Plate against the Asian continent is considered to have occurred in an ocean-ward (northeastward) direction, although the velocity was only $1 \mathrm{~cm}$ per year in the ocean-ward component (Engebretson, Cox \& Gordon, 1985). Both the trench roll-back and ocean-ward direction of the subducting oceanic plate may have caused rapid extension of continental crust and upwelling of the asthenosphere along the eastern margin of the Asia during Late Jurassic times (Fig. 8, a.2).

\section{5.b. Stage II (Berriasian: formation of island-arc volcanic islands)}

Stage II is defined by the predominance of trachyandesitic volcano-sedimentary rocks (Fig. 8, b.1). Trachyandesitic volcanism climaxed in the latter part of this stage, as represented by the Nakatengu and Nunobe formations and the Chikushidake and Soashibetsu micromonzonite sheets. Palaeocurrent data suggest that the trachyandesitic volcaniclasts of the Nakatengu Formation flowed from the east into the western Yubari Range area and from the west in the eastern Yubari Range area. These flow directions indicate that the main volcanic body was located between the western and eastern Yubari Range areas. The Chikushidake Micromonzonite and Nunobe Formation suggest that another trachyandesite volcano formed in the Nunobe area. Both volcanoes may have emerged above the sea surface, as suggested by the accompanying oolitic limestone.

The relative plate motion of the Pacific oceanic plate against the Asian continent (that is, the Izanagi Plate) changed from ocean-ward (northeastward) to continent-ward (northwestward) during the period (Engebretson, Cox \& Gordon, 1985; Fig. 8, b.2). Trachyandesitic igneous rocks with typical island-arc affinities (high LILE/HFSE ratio and negative anomaly in $\mathrm{Nb}$, described by Takashima et al. 2002) might have influenced the subducting slab of the Izanagi Plate.

\section{5.c. Stage III (Valanginian: rifting and sea-floor spreading)}

Rifting and submarine basaltic volcanism characterize this stage (Fig. 8, c.1). The emerged trachyandesitic volcano subsided into the deep marine region, and basaltic andesitic pillow lava, represented by the Ogurose Formation, erupted in the Nunobe area. Although the Nae area remained in the deep marine environment following Stage I, voluminous basaltic pillow lava erupted contemporaneously. However, no volcanism occurred in the western and eastern Yubari Range areas, where tuffaceous mudstones of the basal Shirikishimanaigawa Formation continued to accumulate.

The Izanagi plate turned northward and subducted obliquely under the Asian continent (Fig. 8, c.2). Niida (1992) noted that the igneous rocks of the Ogurose Formation are alkali basalt with a high $\mathrm{Na}_{2} \mathrm{O} / \mathrm{K}_{2} \mathrm{O}$ ratio that occurs in restricted areas of the transform boundary. These characteristics suggest that the initiation of sinistral strike-slip movement behind the trench caused the basaltic volcanism subsequent to rifting. Contemporaneous submarine basaltic volcanism occurred in the Rebun-Kabato Zone. The formation of pull-apart basins accompanied by sea-floor spreading resembles that of the modern Andaman arc setting.

\section{5.d. Stage IV (Hauterivian-Barremian: cessation of in situ volcanism)}

In situ volcanism in the Sorachi-Yezo Belt was extinct after this stage, which is represented in all study areas by a predominance of tuffaceous mudstone of the Shirikishimanaigawa Formation. The andesitic tuffs and volcanogenic sandstones are thought to have been supplied from the Rebun-Kabato Zone of the western Oshima Belt after the later part of this stage (Kiminami et al. 1992). A westward shift of the volcanic front from the Sorachi-Yezo Belt to the Oshima Belt might have occurred in this stage.

Sinistral strike-slip faults, such as the Tan-Lu Fault, developed extensively in the eastern margin of Asian continent after Hauterivian times (e.g. Okada, 1999). This sinistral strike-slip movement may have disrupted the accretionary complex growth, formed numerous half graben, and uplifted metamorphic belts along the supra-subduction zone (Takahashi \& Matsukawa, 2000). The drastic change in the facies from the submarine volcano-sedimentary successions of the Sorachi Group to the terrigenous successions of the Yezo Group suggests the influence of the above-mentioned geodynamics.

\section{Summary}

The Late Jurassic-Early Cretaceous period was characterized by the significant reconfiguration of oceanic plate movement in the NW Pacific. The Upper Jurassic ophiolite and Lower Cretaceous island-arc volcanosedimentary covers of the Sorachi Group were formed within the island-arc setting off the eastern margin of the Asian continent. Therefore, the group records the volcanism and sedimentation associated with the 
changing movement of the subducting oceanic plate during that interval. Stratigraphic changes in the nature and volume of volcanic and volcaniclastic rocks of the Sorachi Group indicate four tectonic stages.

Stage I was characterized by extensive submarine eruptions of BABB-type-tholeiitic basalt. Slab rollback caused rifting and sea-floor spreading of the suprasubduction zone along the active Asian continental margin during this stage.

Stage II has been dated to the Berriasian and included localized trachyandesitic volcanism that formed volcanic islands with chemical compositions typical of island-arc settings. The direction of the Pacific oceanic plate movement shifted from northeastward to northwestward at the beginning of this stage.

Stage III, in the Valanginian, was characterized by submarine basaltic volcanism followed by subsidence. The Pacific oceanic plate motion turned clockwise, and plate conjugation between the Asian continent and the Pacific oceanic plate changed from a convergent to a transform boundary. The formation of pull-apart basins accompanied by sea-floor spreading was similar to that of formations occurring in the modern Andaman arc setting.

Stage IV coincided with the Hauterivian-Barremian. In this stage, in situ volcanism ceased in the SorachiYezo basin, and the volcanic front migrated from the Sorachi-Yezo Belt to the Oshima Belt. This sinistral strike-slip movement is thought to have disrupted growth of the accretionary complex, and formed numerous half graben and uplifted metamorphic belts along the supra-subduction zone in the eastern margin of the Asian continent.

Acknowledgements. We express sincere gratitude to Professors Tunemasa Saito, Keiichi Shiraki, Jun-ichi Kimura and Taniel Danelian for helpful suggestions, and Laurent Jolivet and A. J. Barber for helpful reviews, which improved the paper considerably. We also thank Ikuo Takahashi, Yasunori Miyamoto, Shigeaki Kamota (Tokyo University), Kazuo Kobayashi, Kou Takashima and Koichi Matsuda for support during our fieldwork. This study was supported financially by the JSPS Research Fellows Scheme (No. 07622), 21st Century Center of Excellence (COE) Program on 'Natural History' at Hokkaido University.

\section{References}

Ando, A., Kakegawa, T., Takashima, R. \& Saito, T. 2002. A new perspective on Aptian carbon isotope stratigraphy: constraints from $\delta^{13} \mathrm{C}$ records of terrestrial organic matter. Geology 30, 227-30.

ANDO, A., KAKEGAWA, T., TAKASHIMA, R. \& SAITO, T. 2003. Stratigraphic carbon isotope fluctuations of detrital woody materials during the Aptian Stage in Hokkaido, Japan: comprehensive $\delta^{13} \mathrm{C}$ data from four sections of the Ashibetsu area. Journal of Asian Earth Sciences 21, 835-47.

Baumgartner, P. O., Bartolini, A., Carter, E. S., Conti, M., Cortese, G., Danelian, T., De Wever, P., Dumitrica, P., Dumitrica-Jud, R., Corican, S.,
Guex, J., Hull, D. M., Kito, N., Marcucci, M., MATSuOKA, A., Murchey, B., O'Dogherty, L., SaVAry, J., VishneVskaYA, V., WidZ, D. \& YaO, A. 1995. Middle Jurassic to Early Cretaceous radiolarian biochronology of Tethys based on unitary associations. In Middle Jurassic to Lower Cretaceous Radiolaria of Tethys: Occurrences, systematics, biochronology (eds P. O. Baumgartner, L. O'Dogherty, G. Spela, E. Urquhart, A. Pillevuit and P. De Wever), pp. 1013-43. Lausanne: Buchbinderei Schumacher.

Engebretson, D. C., Cox, A. \& Gordon, R. G. 1985. Relative motions between oceanic and continental plates in the Pacific Basin. Geological Society of America, Special Paper no. 206, 59 pp.

Enkin, R. J., Yan, C., Courtillot, V., Besse, J., Xing, L. S., Zhang, Z. H., ZhuANG, Z. G. \& ZhANG, J. X. 1991. A Cretaceous Pole from South China, and the Mesozoic Hairpin Turn of the Eurasian Apparent Polar Wander Path. Journal of Geophysical Research-Solid Earth and Planets 96, 4007-27.

Girard, M., Jolivet, L., NAKagawa, M., Aguirre, L. \& NIIDA, K. 1991. Acidic volcanic products in Lower Cretaceous deposits of the Sorachi-Yezo Belt, Hokkaido, northeast Japan. Journal of Geological Society of Japan 97, 1-14.

HoSHI, H. \& TAKASHIMA, R. 1999. Paleomagnetic analysis for some volcanic rocks of the Sorachi Group in the Furano area, central Hokkaido, Japan. Bulletin of the Mikasa City Museum, Natural Science, no. 3, 23-30 (in Japanese with English abstract).

IsHIZUKA, H. 1980. Geology of the Horokanai Ophiolite in the Kamuikotan Tectonic Belt, Hokkaido, Japan. Journal of Geological Society of Japan 86, 119-34 (in Japanese with English abstract).

IsHIZUKA, H. 1981. Geochemistry of the Horokanai Ophiolite in the Kamuikotan Tectonic Belt, Hokkaido, Japan. Journal of Geological Society of Japan 87, $17-34$.

ITO, T. 2002. Active faulting, lower crustal delamination and ongoing Hidaka arc-arc collision, Hokkaido, Japan, In Seismotectonics in Convergent Plate Boundary (eds Y. Fujinawa and A. Yoshida), pp. 219-24. Tokyo: Terrapub (in Japanese with English abstract).

JiANG, Y.-H., LING, H.-F., JiANG, S.-Y., FAN, H.-H., JiANG, W.-Z. \& NI, P. 2005. Petrogenesis of a Late Jurassic peraluminous volcanic complex and its high-Mg, potassic, quenched enclaves at Xiangshan, southeast China. Journal of Petrology 46, 1121-54.

Jolivet, L., SHIBUYA, H. \& FoURNIER, M. 1995. Paleomagnetic rotations and the Japan Sea opening. In Active margins and marginal basins of the western Pacific (eds B. Taylor and J. Natland), pp. 355-69. Geophysical Monograph no. 88. Washington: American Geophysical Union.

Kiminami, K., Komatsu, M., NiIDA, K. \& Kito, N. 1986. Tectonic divisions and stratigraphy of the Mesozoic rocks of Hokkaido, Japan. In Geology and tectonics of Hokkaido (eds Editorial Committee of Geology and Tectonics of Hokkaido, Sapporo Branch of Association for the Geological Collaboration in Japan), pp. 115. Monograph of the Association for Geological Collaboration in Japan, no. 31. Tokyo: The Association for Geological Collaboration in Japan (in Japanese with English abstract).

Kiminami, K., NiIDA, K., ANDO, H., Kito, N., Iwata, K., MiYAShitA, S., TAJIKA, J. \& SAKaKibARA, M. 1992. 
Cretaceous-Paleogene arc-trench systems in Hokkaido. In 29th IGC field trip guidebook (eds M. Adachi and K. Suzuki), pp. 1-43. Nagoya: Nagoya University.

KIMURA, G. 1986. Oblique subduction and collision: Forearc tectonics of the Kuril arc. Geology 14, 404-7.

KIRILlOVA, G. L. 2003a. Cretaceous tectonics and geological environments in East Russia. Journal of Asian Earth Sciences 21, 967-77.

KIRILlOVA, G. L. 2003b. Late Mesozoic-Cenozoic sedimentary basins of active continental margin of Southeast Russia: paleogeography, tectonics, and coal-oil-gas presence. Marine and Petroleum Geology 20, 38597.

KITO, N. 1987. Stratigraphic relation between greenstones and clastic sedimentary rocks in the Kamuikotan Belt, Hokkaido, Japan. Journal of the Geological Society of Japan 93, 21-35 (in Japanese with English abstract).

KITO, N. 1995. Upper Jurassic to Lower Cretaceous stratigraphy of Hokkaido, Japan. In Middle Jurassic to Lower Cretaceous Radiolaria of Tethys: Occurrences, systematics, biochronology (eds P. O. Baumgartner, L. O'Dogherty, G. Spela, E. Urquhart, A. Pillevuit and P. De Wever), pp. 923-35. Lausanne: Buchbinderei Schumacher.

Kito, N., Kiminami, K., NiIDA, K., Kanie, Y., Watanabe, T. \& KawaGUCHI, M. 1986. The Sorachi Group and the Yezo Supergroup. In Geology and tectonics of Hokkaido (eds Editorial Committee of Geology and Tectonics of Hokkaido, Sapporo Branch of Association for the Geological Collaboration in Japan), pp. 8196. Monograph of the Association for the Geological Collaboration in Japan, no. 31. Tokyo: The Association for Geological Collaboration in Japan (in Japanese with English abstract).

Li, X-H., Chung, S-L., Zhou, H., Lo, C-H., Liu, Y. \& CHEN, C.-H. 2004. Jurassic intraplate magmatism in southern Hunan-eastern Guangxi: ${ }^{40} \mathrm{Ar} /{ }^{39} \mathrm{Ar}$ dating, geochemistry, $\mathrm{Sr}-\mathrm{Nd}$ isotopes and implications for the tectonic evolution of SE China. In Aspects of the Tectonic Evolution of China (eds J. Malpas, C. J. N. Fletcher, J. R. Ali and J. C. Aitchison), pp. 193215. Geological Society of London, Special Publication no. 226.

LOWE, D. R. 1982. Sediment gravity flows: II. Depositional models with special reference to the deposits of highdensity turbidity currents. Journal of Sedimentary Petrology 52, 279-97.

Meng, Q. R. 2003. What drove late Mesozoic extension of the northern China-Mongolia tract? Tectonophysics 369, 155-74.

Minoura, N., Kumano, S., Kito, N., KAMADA, K. \& Kato, M. 1982. Lower Cretaceous deposits at Nunobe, Central Hokkaido. Chikyu Kagaku 36, 348-50 (in Japanese with English abstract).

MolnAR, P. \& ATWATER, T. 1978. Interarc spreading and Cordilleran tectonics as alternates related to the age of subducted oceanic lithosphere. Earth and Planetary Science Letters 41, 330-40.

NAKANISHI, M., TAMAKI, K. \& KoBAYASHI, K. 1992. Magnetic anomaly lineations from Late Jurassic to Early Cretaceous in the west-central Pacific-Ocean. Geophysical Journal International 109, 701-19.

NIIDA, K. 1992. Basalts and dolerites in the Sorachi-Yezo Belt, central Hokkaido, Japan. Journal of Faculty of Science, Hokkaido University, Series 4, 23, 301-19.
OgG, J. G., Agterberg, F. P. \& Gradstein, F. M. 2004. The Cretaceous period. In A Geologic Time Scale 2004 (eds F. M. Gradstein, J. G. Ogg and A. Smith), pp. 344-83. Cambridge: Cambridge University Press.

OKADA, H. 1974. Migration of acient arc-trench systems. In Modern and ancient geosynclinal sedimentation (eds R. J. H. Dott and R. H. Shaver), pp. 311-20. Society of Economic Paleontologists and Mineralogists, Special Publication no. 19.

OKADA, H. 1999. Plume-related sedimentary basins in East Asia during the Cretaceous. Palaeogeography, Palaeoclimatology, Palaeoecology 150, 1-11.

OKada, H., Tarduno, J. A., NAKaseko, K., Nishimura, A. \& SLITER, W. V. 1991. Reexamination of the age of the uppermost sequence of the Sorachi Group in its type area, Hokkaido, Japan. Memoirs of the Faculty of Science, Kyushu University 27, Series D, Earth and Planetary Sciences, 1-13.

OSOZAWA, S. 1994. Plate reconstruction based upon age data of Japanese accretionary complexes. Geology 22, 11358.

OXMAN, V. S. 2003. Tectonic evolution of the Mesozoic Verkhoyansk-Kolyma belt (NE Asia). Tectonophysics 365, 45-76.

Ren, J. Y., TAMKI, K., LI, S. T. \& JUNXIA, Z. 2002. Late Mesozoic and Cenozoic rifting and its dynamic setting in Eastern China and adjacent areas. Tectonophysics 344, 175-205.

SAKAShima, T., TeradA, K., TAKeshita, T. \& SANO, Y. 2003. Large-scale displacement along the Median Tectonic Line, Japan: evidence from SHRIMP zircon $\mathrm{U}-\mathrm{Pb}$ dating of granites and gneisses from the South Kitakami and paleo-Ryoke belts. Journal of Asian Earth Sciences 21, 1019-39.

SEWELL, R. J. \& CAMPBELL, S. D. G. 1997. Geochemistry of coeval Mesozoic plutonic and volcanic suites in Hong Kong. Journal of the Geological Society, London 154, 1053-66.

TAKAHASHI, O. \& MATSUKAWA, M. 2000. Oceanward shifting of the Hauterivian (Early Cretaceous) arc-trench system in East Asia. Geosciences Journal 4, 187-99.

TAKASHIMA, R., KaWABE, F., Nishi, H., MORIYA, K., WANI, R. \& ANDO, H. 2004. Geology and stratigraphy of forearc basin sediments in Hokkaido, Japan: Cretaceous environmental events on the north-west Pacific margin. Cretaceous Research 25, 365-90.

TAKashima, R., Nishi, H., MiYamoto, Y. \& Yoshida, T. 2002. Geology and stratigraphy of the Sorachi and Yezo groups in the Tokyo University Forests in Hokkaido, Japan. Bulletin of Tokyo University Forests 108, 57-76 (in Japanese with English abstract).

TAKASHIMA, R., NISHI, H. \& YOSHIDA, T. 2001. Stratigraphy and sedimentary environment of the Sorachi and Yezo Groups in the Yubari-Ashibetsu area, Hokkaido, Japan. Journal of the Geological Society of Japan 107, 1-20 (in Japanese with English abstract).

TAKASHIMA, R., YoshidA, T. \& Nishi, H. 2002. Geology, petrology and tectonic setting of the Late Jurassic ophiolite in Hokkaido, Japan. Journal of Asian Earth Sciences 21, 197-215.

TAKEUChI, T., KODAMA, K. \& OZAWA, T. 1999. Paleomagnetic evidence for block rotations in central Hokkaidosouth Sakhalin, Northeast Asia. Earth and Planetary Science Letters 169, 7-21.

TAZAWA, J. 2002. Late Paleozoic brachiopod faunas of the South Kitakami Belt, northeast Japan, and thier 
paleobiogeographic and tectonic implications. The Island Arc 11, 287-301.

TAZAWA, J. 2004. The strike-slip model: A synthesis on the origin and tectonic evolution of the Japanese Islands. Journal of Geological Society of Japan 110, 503-17 (in Japanese with English abstract).

UEDA, H. \& MiYASHITA, S. 2005. Tectonic accretion of a subducted intraoceanic remnant arc in Cretaceous Hokkaido, Japan, and implications for evolution of the Pacific northwest. The Island Arc 14, 582-98.
Van Der Voo, R., Spakman, W. \& BijwaArd, H. 1999. Mesozoic subducted slabs under Siberia. Nature 397, 246-9.

Zonenshain, L. P., KuZmin, M. I. \& Natapov, L. M. 1990. Geology of the USSR: a plate-tectonic synthesis. Geodynamics Series no. 21. Washington: American Geophysical Union, 242 pp.

ZorIN, Y. A. 1999. Geodynamics of the western part of the Mongolia-Okhotsk collisional belt, Trans-Baikal region (Russia) and Mongolia. Tectonophysics 306, 33-56. 